\title{
Magnetic dating of the Holocene monogenetic Tkarsheti volcano in the Kazbeki region (Great Caucasus)
}

\author{
Goga Vashakidze ${ }^{1}$, Avto Goguitchaichvili ${ }^{*}{ }^{*}$, Natalia García-Redondo ${ }^{3}$, Manuel Calvo-Rathert ${ }^{3,6}$, \\ Ángel Carrancho ${ }^{4}$, Ruben Cejudo², Juan Morales², Vladimir A. Lebedev ${ }^{5}$ and Ketino Gabarashvili ${ }^{1}$
}

\begin{abstract}
The radiocarbon technique is widely used to date Late Pleistocene and Holocene lava flows. The significant difference with palaeomagnetic methods is that the ${ }^{14} \mathrm{C}$ dating is performed on the organic matter carbonized by the rock formation or the paleosols found within or below the lava flow. On the contrary, the archaeomagnetic dating allows to date the moment when the lava is cooling down below the Curie temperatures. In the present study, we use the paleomagnetic dating to constrain the age of the Tkarsheti monogenetic volcano located within the Kazbeki Volcanic Province (Great Caucasus). A series of rock-magnetic experiments including the measurement of hysteresis curves, isothermal remanence, back-field and continuous thermomagnetic curves were applied. These experiments indicated that Pseudo-Single-Domain Ti-poor titanomagnetite is responsible for remanence. A characteristic remanent magnetization was obtained for all twenty analyzed samples yielding a stable single magnetization component observed upon both thermal and alternating field treatments. Comparison of the mean directions obtained $\left(\mathrm{InC}=48.6^{\circ}\right.$, $\mathrm{Dec}=6.4^{\circ}, \mathrm{A}_{95}=4.0^{\circ}$ and $\mathrm{K}=67$ ) with the SCHA.DIF.14k model yielded two main time intervals (4740-4650 or 4427$4188 \mathrm{BC}$ ) as the best age estimate of the Lesser Tkarsheti lava flow. These results suggest an earlier age (between approximately 200 and 700 years) for this monogenetic lava flow than expected from the estimated age provided by a former ${ }^{14} \mathrm{C}$ dating obtained in 1973 on woody remains. This first attempt to use the archaeomagnetic technique in the Caucasus indicates that the SCHA.DIF.14k geomagnetic model may be successfully used for dating purposes in the region
\end{abstract}

Keywords: Great Caucasus, Monogenetic volcano, Kazbeki, Magnetic dating

\section{Introduction}

Archaeomagnetism and palaeomagnetism are powerful and useful tools of dating of burned archeological artifacts. However, an interesting, though not sufficiently explored, application of thermoremanent magnetization is its use as a dating tool for volcanic rocks since lavas can acquire a remanent magnetization recording the characteristics of the Earth's magnetic field (EMF) existing during their formation. If the variations of the EMF in the past are known with precision, it is possible

\footnotetext{
${ }^{*}$ Correspondence: avto@igeofisica.unam.mx

${ }^{2}$ National Archaeomagnetic Service, Institute of Geophysics, National University of Mexico (UNAM), Mexico, Mexico

Full list of author information is available at the end of the article
}

to establish a temporal variation record, such as a secular variation curve which can be used as a dating method known as paleomagnetic dating which can be as accurate as the radiometric dating method (Tauxe 2010). The ${ }^{14} \mathrm{C}$ method is commonly used to date Late Pleistocene and Holocene rocks $(<40 \mathrm{ka})$. However, this dating is often done with carbon associated with the rock formation or paleosol that lies below or above the studied unit, potentially causing an incorrect interpretation of the age of the site (Siebe et al. 2004). The magnetic method has a significant advantage, since it allows dating the moment of rock formation if the remanence carried by the sample is found to be of primary origin. On the other hand, the K/ Ar and ${ }^{40} \mathrm{Ar} /{ }^{39} \mathrm{Ar}$ methods are unable to date Holocene volcanic eruptions and thus paleomagnetism becomes a 
powerful alternative method to date lavas formed during the last 14,000 years (Di Chiara 2013; Di Chiara et al. 2014a, b, 2017; Roperch et al. 2015).

Palaeomagnetism and archaeomagnetism are an interdisciplinary branch of geophysics that investigates the variations of the Earth's magnetic field in terms of declination, inclination and absolute intensity. In practice, this is a dating method that consists in comparing the paleodirections recorded in burned archeological artifacts or recent volcanic lava flows with a regional secular variation reference (master) curve. Pavon Carrasco et al. (2011) developed a Matlab tool for magnetic dating purpose based on the combination of temporal probability density functions of the three geomagnetic field elements. In this study, we used paleosecular variation curve retrieved from SHA.DIF.14k geomagnetic field model (Pavon Carrasco et al. 2014) updated with recently published archaeomagnetic and volcanic data.

The Caucasus area is characterized by a significant and uninterrupted volcanic activity from the Jurassic to the present day (e.g., Rebaï et al. 1993). Since the 1990s, new paleomagnetic and paleointensity studies have been performed in Georgia, applying modern procedures and quality criteria (Calvo-Rathert et al. 2015; SánchezMoreno et al. 2018, and references therein) Nevertheless, high-quality archaeomagnetic data are still scarce. In this study, we tried to date a Holocene monogenetic volcano located in the Kazbeki Volcanic Province by means of a paleomagnetic age determination using the SHA.DIF.14K model for the first time in the Caucasus.

\section{Rudiments of local geology and location}

The recent geodynamics of the Caucasus region is related to the convergence Eurasian and Africa-Arabian plates, giving rise to Neogene-Quaternary volcanism in different regions of Georgia, including the Great Caucasus (e.g., Adamia et al. 2011). The Kazbeki stratovolcano is located in the central part of the Main Caucasus Range, between Russia and Georgia. Its intense magmatic activity led to the formation of numerous large (up to $15 \mathrm{~km}$ ) and thick (up to hundreds of meters) lava flows, the long upper ones reaches the Tergi River. On the periphery of the main cone, there are more than ten volcanic edifices of different ages, including monogenic and polygenic scoria cones, extrusive domes and small explosion centers (Chernyshev et al. 1999). The Kazbeki Center is located in the southeastern sector of the volcanic area in the axial part and on the southern slope of the sublatitudinal Khokh Range (one of the links of the Lateral Range). It covers an area of approximately $250 \mathrm{~km}^{2}$ in the upper Tergi basin. This volcanic field also includes the Devdoraki, Chkheri, Kesia, Mnaisi and Suatisi sub-structures among some other minor buildings. The northern boundary of the youngest volcanism passes along the sources of the Maili and Chachi glaciers, further along the valley of the Devdoraka River up to the Daryal Gorge and then cut through the Tergi River in Paleozoic granites. To the north-west, the territory of the Kazbeki center ends at the Suatisi glacier and the Dzhimara summit (Lebedev et al. 2018). The Kazbeki Volcanic Field includes a Kazbeki $(5033 \mathrm{~m})$ stratovolcano located in the middle of the caldera of its predecessor, Paleo-Kazbeki (Dzotsenidze et al. 1985; Koronovskii and Demina 2003; Lebedev et al. 2014), and more than ten satellite volcanoes located from the east, south and west sides of the arc such as the Big Tkarsheti, Shevardeni and Kechuttsveri. Available radiometric data together with the interpretation of detailed satellite images, the chemical composition of volcanic cones and their lava flows allowed to determine four main magmatic phases in the Kazbeki volcanic field: phase I: 460-380 ka; phase II: 310-200 ka; phase III: 130-90 ka and phase IV: less than 50 thousand years ago. In addition, within the specified periods of phases II and III, early and late stages are additionally distinguished (Lebedev et al. 2018).

The Monogenic volcano Lesser Tkarsheti $(2214 \mathrm{~m})$ studied here (Fig. 1) is a small cone located in the valley of the Tergi river at an altitude of about $400 \mathrm{~m}$ above the sea level near the village of Goristsikhe. A single eruption of the volcano led to the formation of a short (up to $1 \mathrm{~km}$ ) andesitic lava flow. This flow blocked the valley of the Tergi river forming a relatively deep (up to $350 \mathrm{~m}$ ) lake. Numerous woody remains are found in this stratum yielding a ${ }^{14} \mathrm{C}$ age of about $\sim 6000$ years (Burchuladze et al. 1976; Chernyshev et al. 2002). This single radiometric dating was performed by Djanelidze et al. (1973), who reported an age of $5950 \pm 60$ BP for sample TB-44 analyzed in the ${ }^{14} \mathrm{C}$ laboratory of the Tbilisi State University. This allows to attribute the eruption of the Lesser Tkarsheti lava flow to the middle of the Holocene period.

\section{Laboratory measurements}

Several magnetic experiments were carried out to recover all components of the primary, characteristic remanent magnetization and to identify the magnetic carriers, their thermal stability and their domain state. Alternating field demagnetization cleaning protocols were run to isolate the remanent magnetization on 20 samples using the $2 \mathrm{G}$ superconductor cryogenic magnetometer equipped with AF demagnetizer. This allowed performing a detailed stepwise alternating field and thermal demagnetization of 20 samples.

Continuous high-field magnetization versus temperature curves, hysteresis cycles, back-field curves and isothermal remanent magnetization (IRM) acquisition curves were measured with a Variable Field Translation 

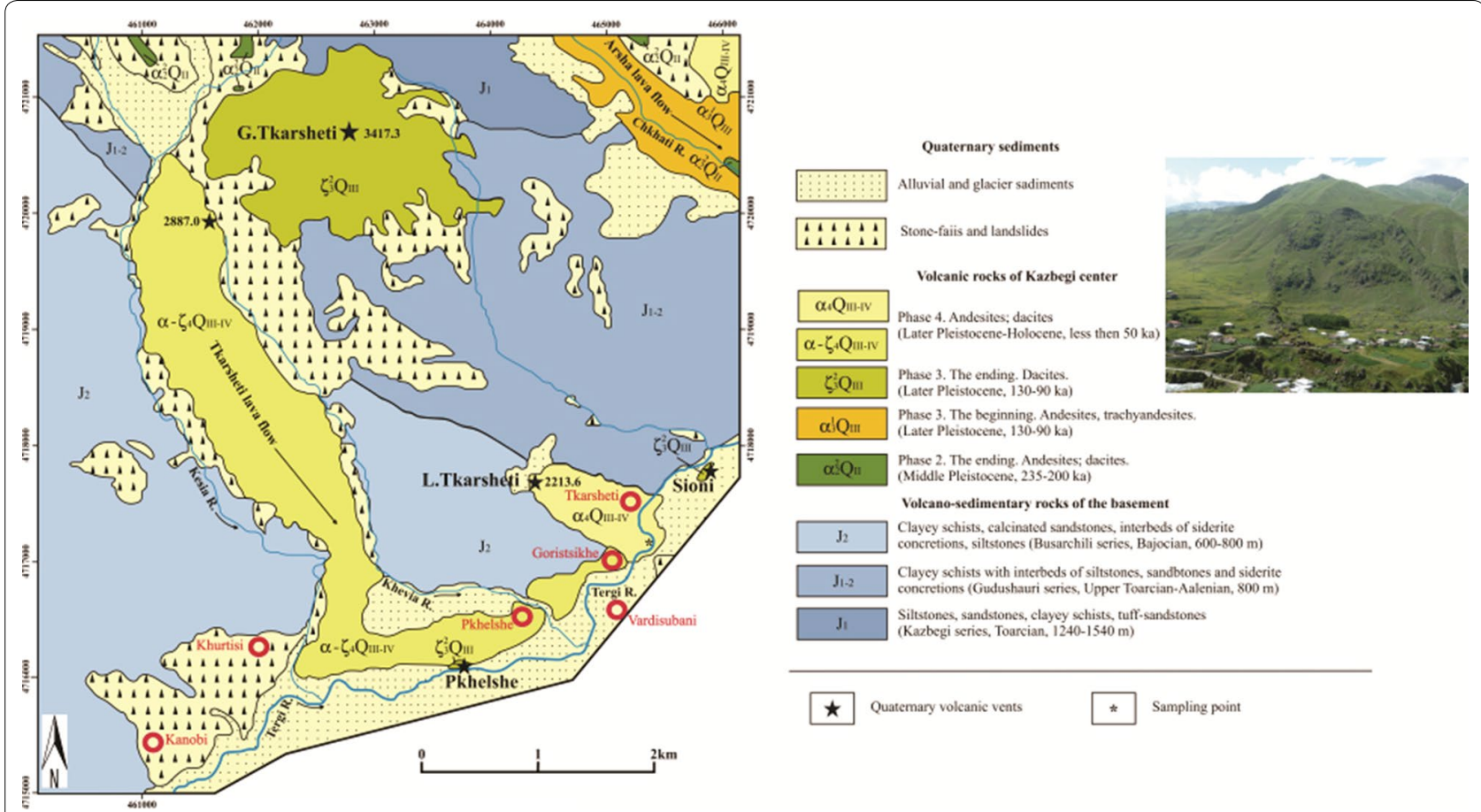

Fig. 1 Simplified geological map of the Tkarsheti volcano and its lava flow $\left(42^{\circ} 36^{\prime} 42 \mathrm{~N}, 44^{\circ} 34^{\prime} 31 \mathrm{E}\right)$ in the Tergi valley [see text for more details (redrawn from Lebedev et al. 2018)]. Also shown is a general view of Holocene Tkarsheti lava flow near to village Goristsikhe

Balance. Magnetization vs. temperature curves were recorded in air between room temperature and $600{ }^{\circ} \mathrm{C}$ at a rate of $15{ }^{\circ} \mathrm{C}$ per min. A maximum applied field of $0.85 \mathrm{~T}$ was used for IRM acquisition curves. Corrections for paramagnetic and diamagnetic contributions were applied to correctly determine hysteresis parameters. The RockMag Analyser 1.0 software (Leonhardt 2006) was used for the analysis of rock-magnetic results.

\section{Results and concluding remarks}

Thermomagnetic experiments exhibited very similar magnetic mineralogy and thermal behavior for all samples. An acceptable reversible behavior was observed in thermomagnetic curves after comparison of the heating and cooling cycles (Fig. 2), suggesting that magnetite or Ti-poor titanomagnetite could be the main magnetic carrier. Hysteresis curves can provide important information for the analysis of magnetic characteristics of the studied samples through key parameters such as saturation magnetization, saturation remanence, coercivity and coercivity of remanence. Although the use of a Day diagram (Day et al. 1977) for domain-state diagnosis may yield ambiguous interpretations (Roberts et al. 2018), considering that magnetite is the only remanence-carrying mineral found in the samples, in the present case hysteresis ratios may point towards a pseudo-single-domain (PSD) behavior. However, hysteresis parameter ratios pointing towards a PSD domain state may also be interpreted as being produced by a mixture of non-interacting single-domain (SD) and multi-domain (MD) grains (Dunlop, 2002). IRM acquisition curves show evidence of the presence a ferromagnetic (s.l.) phase characterized by low to moderate coercivity, because saturation is attained below $300 \mathrm{mT}$. All samples were demagnetized either by alternating fields up to $95 \mathrm{mT}$ or thermal treatment up to $575{ }^{\circ} \mathrm{C}$. Analysis of demagnetization behavior shows the presence of a single main paleomagnetic component, and no significant viscous overprints are observed. The median destructive fields (MDF) which characterize alternating-field demagnetization behavior yield values between 30 and $45 \mathrm{mT}$ (Fig. 3), suggesting the presence of 'small' PSD magnetic grains.

In ideal case, the local reference secular variation curve should be used for magnetic dating purpose. Tema and Kondopolou (2011) reported a Balkan master curve involving high-quality data (both directions and absolute intensity) mainly from Greece, Bulgaria, Serbia, Hungary and southern Italy. The nearest locality with available archaeomagnetic data is Turkey where Enterpinar et al. (2012) reported a partial curve based on archeological data between 2500 and 700 BCE. Thus, only limited interval of local archaeomagnetic curve is available. As so-called "Fennostack" curve is concerned, we believe that the use of these data is inappropriate because of 

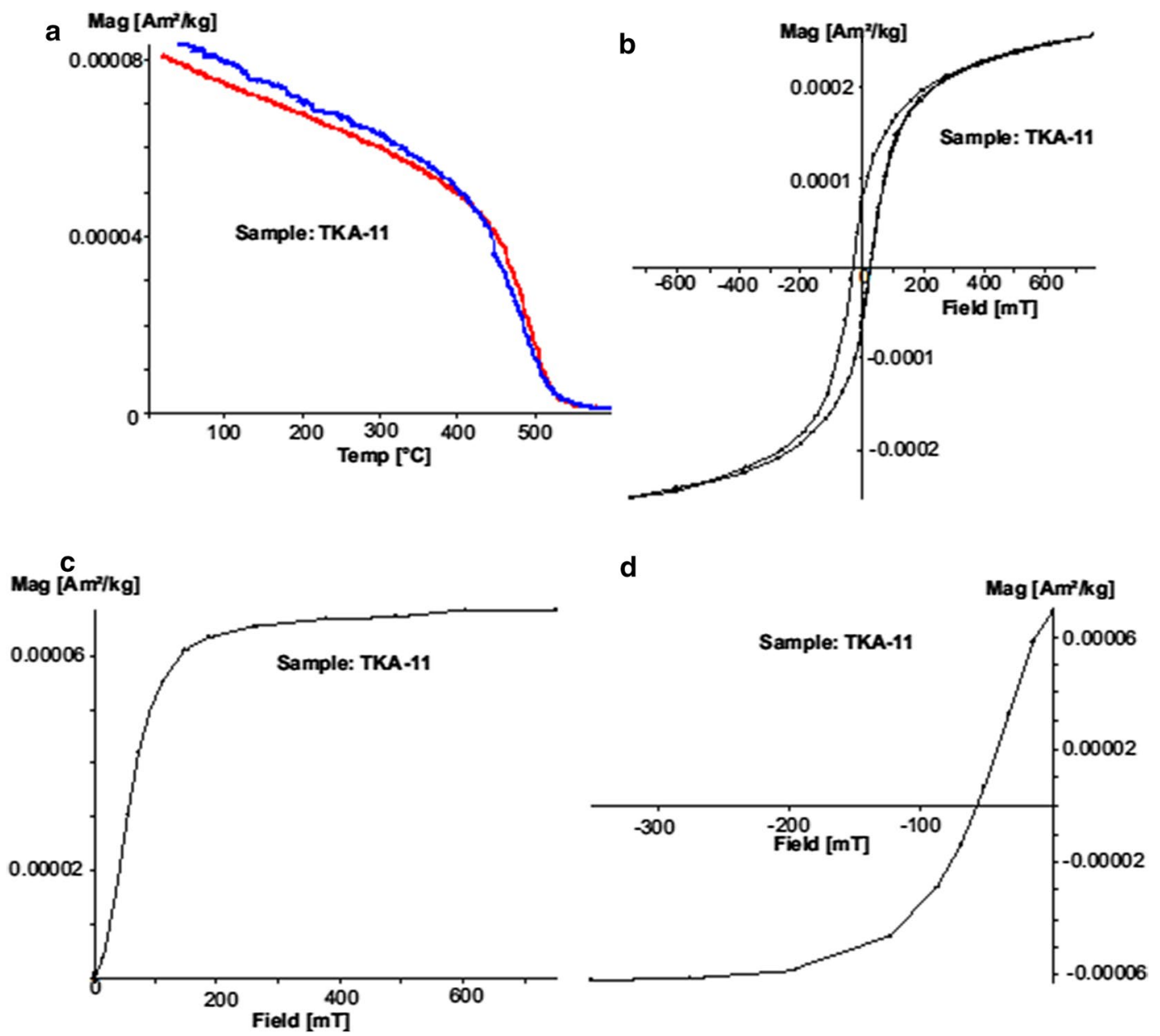

Fig. 2 A summary of rock-magnetic experiments including continuous Ms-T thermomagnetic curve (a). Also shown is Hysteresis cycle (b) with associated isothermal remanence acquisition (c) curves and back-field experiments (d) obtained with a Variable Field Translation Balance

following reasons: this is a standard curve of Holocene secular variation for Fenoscandia (Scandinavia and these countries, see Snowball 2007). Together with this curve, another dataset called "Fennorpis" was also published, a homologous curve but referred to relative intensity variations. Both are made from the paleomagnetic analysis of Holocene varve sediments which do not carry thermoremanent magnetization. Consequently, it cannot be used for chronometric purpose. The same is true for most of CALSK family global curves (Korte and Constable et al. 2009, 2011). In any case, for the dating purposes, the best medium is the Pavón-Carrasco et al. (2014) curve because it is a global model but most data come from Europe avoiding the error of relocation. Although theoretically it covers the last $14 \mathrm{ky}$, the last $6 \mathrm{ky}$ is documented in greater details.

The mean direction was calculated using ChRM directions from all 20 demagnetized samples, yielding the following result: Inclination $=48.6^{\circ}$,
Declination $=6.4^{\circ}, a_{95}=4.0^{\circ}$ and $k=67.1$ (Fig. 4). This result has been introduced in the SCHA.DIF.14k geomagnetic model (Pavón-Carrasco et al. 2014) using the archaeo_dating software of Pavón-Carrasco et al. (2011). In accordance with the probability density function, the main eruption phase of the Tkarsheti volcano is estimated between $4740-4650$ and $4427-4188$ BC. A third time interval between 4089 and 3935 could also be possible, although less probable (Fig. 5). These results suggest an earlier age (between approximately 200 and 700 years) for the Lesser Tkarsheti lava flow than expected from the estimated age provided by the ${ }^{14} \mathrm{C}$ dating obtained in 1973 on woody remains found in the river. Radiocarbon dating may occasionally present some technical problems. One of the main problems of the radiocarbon method is related to the existence of so-called "plateaus". These sub-horizontal segments without apparent variation in certain chronological 


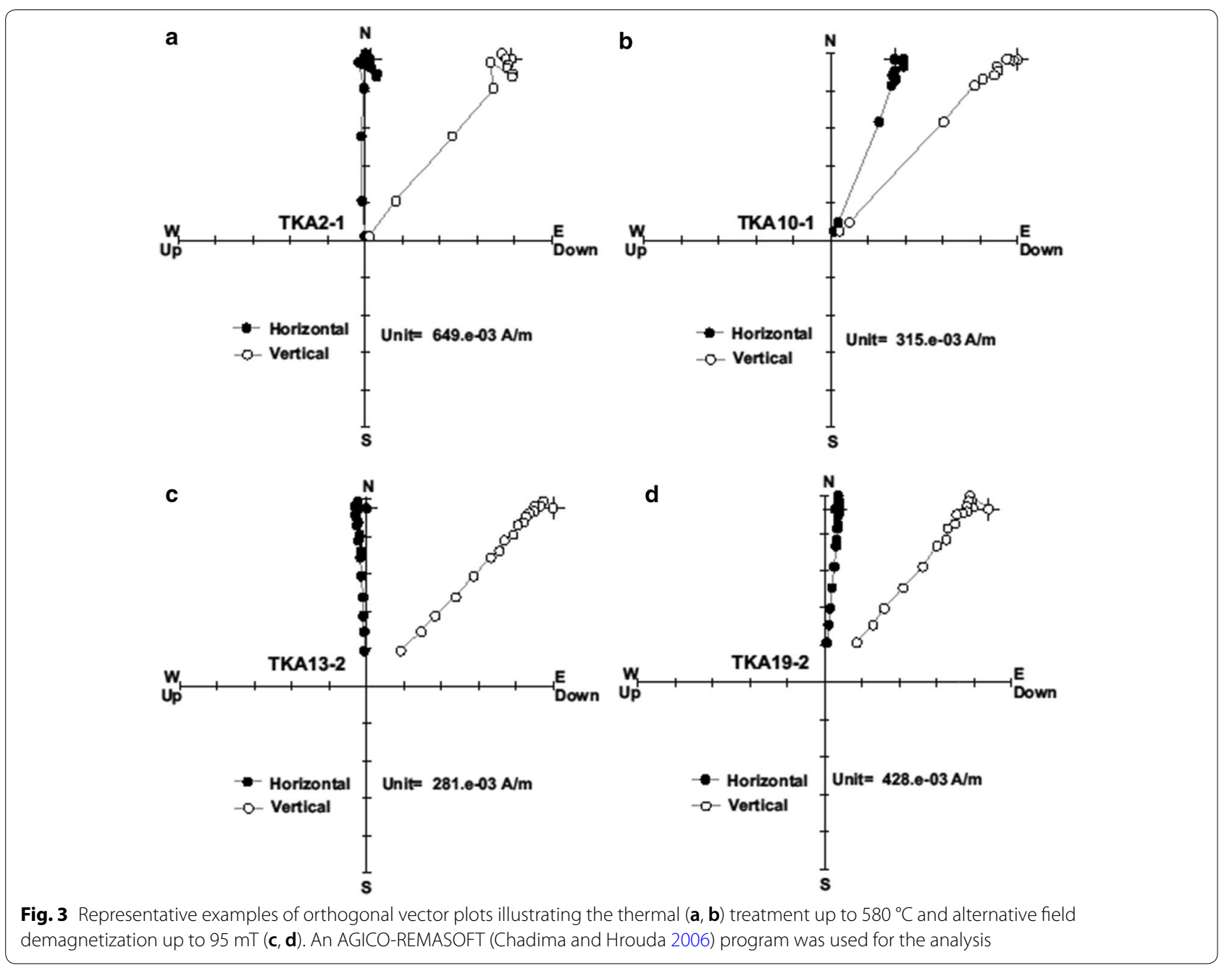

periods make impossible the accurate dating. A wellknown example is the "Hallstatian plateau" (ca. 800$400 \mathrm{BCE})$ and which archeologically coincides with the end of the Iron Age I in Western Europe. Recently, Hervé and Lanos (2017) estimated that radiocarbon dating in that interval of the Hallstatian Plateau could hardly be more precise than 200 to 250 years. Moreover, radiocarbon may have other important problems: (i) The effect of "old wood" (it is not the same to date a fragment of coal from a small wood than one from a large log, because there may be centuries of difference). (ii) Contamination of samples by contact with modern carbon. (iii) The low presence of collagen (minimum 1\% is needed to perform reliable dating).

This first attempt to use the archaeomagnetic technique in the Caucasus indicates that the SCHA.DIF.14k geomagnetic model may be successfully employed for dating purposes in the region. This opens new

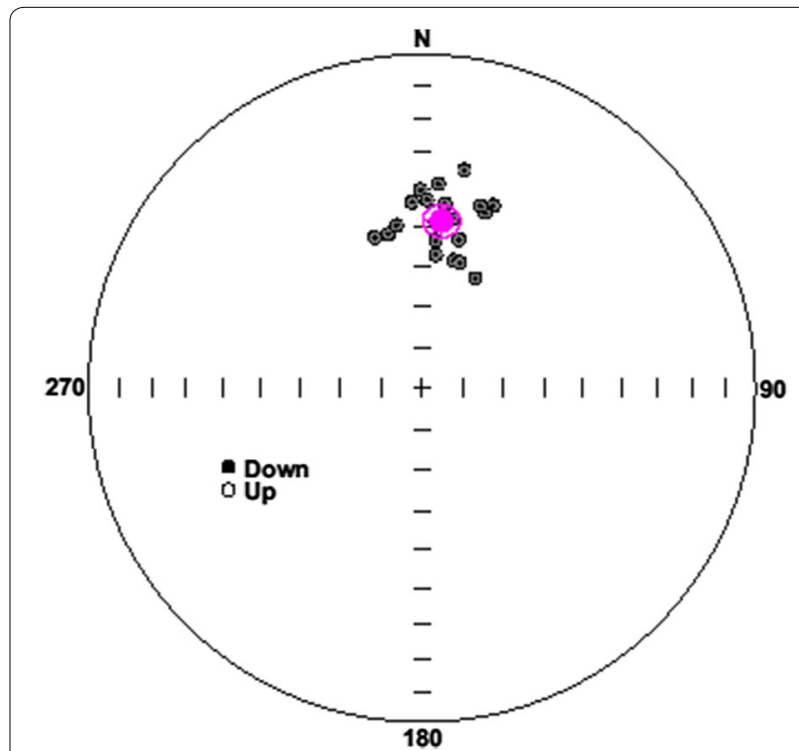

Fig. 4 Equal-area projection of characteristic remanence paleodirections for 20 analyzed samples belonging to Lesser Tkarsheti lava flow 

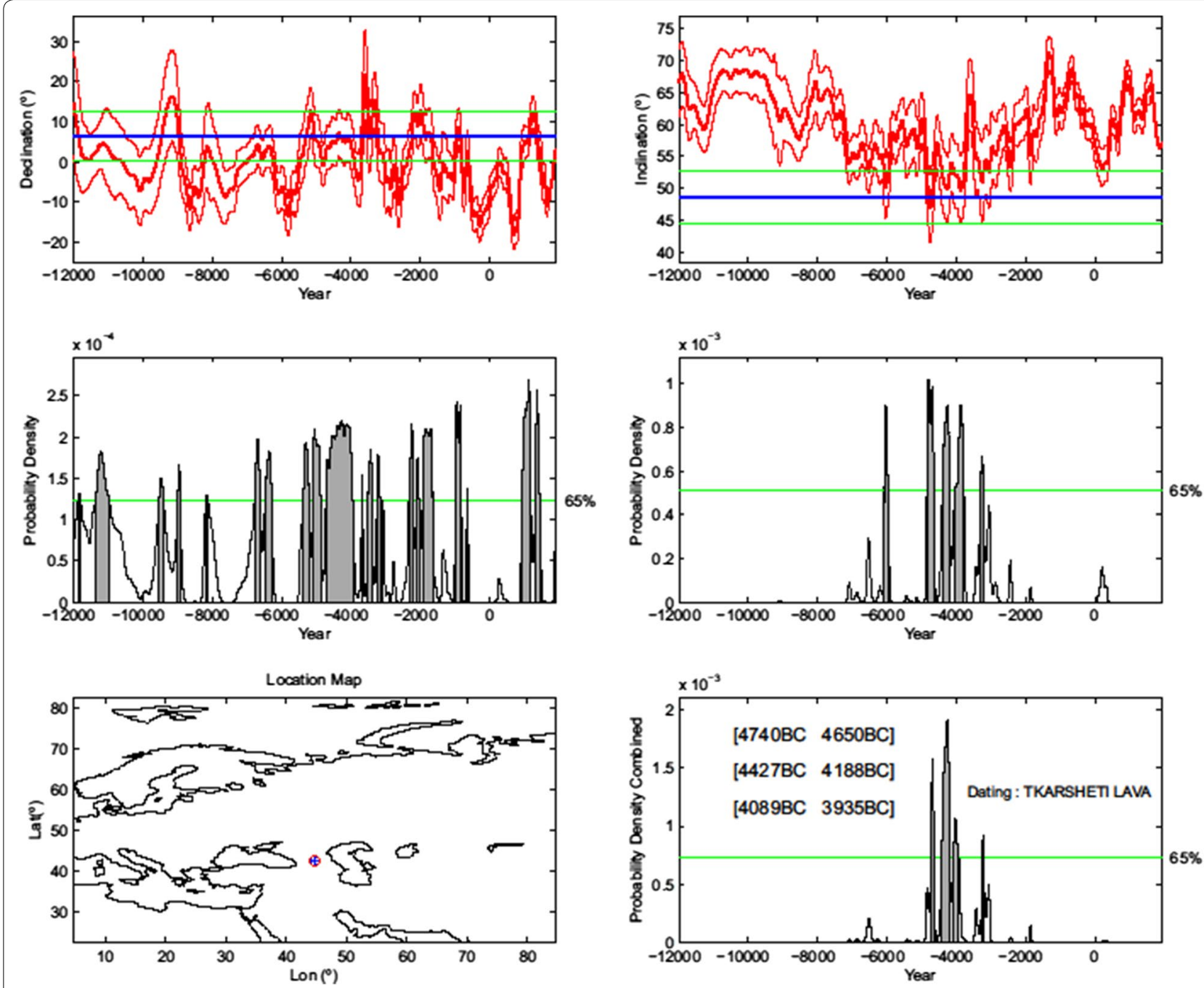

Fig. 5 Archaeomagnetic dating of Lesser Tkarsheti lava using the MATLAB tool provided by Pavón-Carrasco et al. (2011, 2014). See text for more details

opportunities to estimate absolute ages of Great and Lesser Caucasus Holocene volcanic rocks.

\section{Acknowledgements}

No specific acknowledgments.

\section{Authors' contributions}

All authors carefully read and analyzed the manuscript before submitting. GV, AG, MC-R, AC and VL actively participated in the field trip while NG-R performed all natural remanent magnetization measurements. JM and RC carried out rock-magnetic experiments while KG designed and prepared all maps. All authors actively participated in the interpretation and discussion of results. All authors read and approved the final manuscript.

\section{Funding}

This work was funded by projects BU0066U16 and BU235P18 (Junta de Castilla y Leon, Spain) and the European Regional Development Fund (ERDF). AG is grateful for financial support of CONACYT 252149 and UNAM-PAPIIT project 101717. MC-R and AC acknowledge the financial support given by the Junta de Castilla y León (project BU235P18) and the European Regiona Development Fund (ERD). MC-R acknowledges funding from the Fulbright
Commission and the Spanish Ministry of Science, Innovation and Universities for a research stay at the University of Hawaii.

\section{Availability of data and materials}

The datasets used and/or analyzed during the current study are available from the corresponding author on reasonable request.

\section{Competing interests}

The authors declare that they have no competing interests.

\section{Author details}

${ }^{1}$ Institute of Geology, Tbilisi State University, Tbilisi, Georgia. ${ }^{2}$ National Archaeomagnetic Service, Institute of Geophysics, National University of Mexico (UNAM), Mexico, Mexico, ${ }^{3}$ Departamento de Física, EPS, Universidad de Burgos, Av. Cantabria s/n, 09006 Burgos, Spain. ${ }^{4}$ Área de Prehistoria. Departamento de Historia, Geografía y Comunicación, Universidad de Burgos, 09001 Burgos, Spain. ${ }^{5}$ Institute of Geology of Ore Deposits, Petrography, Mineralogy and Geochemistry—Russian Academy of Sciences (IGEM RAS), Moscow, Russia. ${ }^{6}$ Hawaii Institute of Geophysics and Planetology, University of Hawaii, 1680 East-West Road, Honolulu 96822, USA. 
Received: 31 July 2019 Accepted: 13 November 2019

Published online: 03 December 2019

\section{References}

Adamia S, Zakariadze G, Chkhotua T, Sadradze N, Tsereteli N, Chabukiani A Gventsadze A (2011) Geology of the caucasus: a review. Turkish J Earth Sci 20:489-544

Burchuladze AA, Dzhanelidze ChG, Togonidze Gl (1976) Application of radiocarbon method for solution of some problems of Pleistocene and Holocene paleogeograophy of Georgia, Aktual'nye voprosy sovremennoi geokhronologii (Current Problems of Geochronolgy). Nauka, Moscow, pp 238-243

Calvo-Rathert M, Goguitchaichvili A, Vashakidze G, Sologashvili J (2015) New paleomagnetic and paleointensity data from Georgia (Caucasus): a review. Latinmag Lett 5(5):1-22

Chadima M, Hrouda F (2006) Remasoft 3.0-a user friendly paleomagnetic data browser and analyzer. Travaux Geophysiques. XXVII:20-21

Chernyshev IV, Arkelyants MM, Lebedev VA et al (1999) K-Ar isotope systematics and age of lavas from the quaternary kazbek volcanic province, greater caucasus. Dokl Earth Sci 367:862-866

Chernyshev IV, Lebedev VA, Bubnov SN et al (2002) Isotopic geochronology of quaternary volcanic eruptions in the greater caucasus. Geochem Int 40(11):1042-1055

Day R, Fuller M, Schmidt VA (1977) Hysteresis properties of titanomagnetites: grain size and composition dependence. Phys Earth Planet Inter $13: 260-267$

Di Chiara A. (2013). Paleosecular variation of the magnetic field recorded in pleistocene-holocene volcanics from pantelleria (Italy) and Azores archipelago (Portugal): implications for local volcanic history, PhD Thesis, Università degli Studi di Bologna, 151 pp

Di Chiara A, Tauxe L, Speranza F (2014a) Paleointensity determination from Sao Miguel (Azores Archipelago) over the last 3 ka. Phys Earth Planet Interiors 234:1-13

Di Chiara A, Speranza F, Porreca M, Pimentel A, Caracciolo F, Pacheco J DA (2014b) Constraining chronology and time-space evolution of Holocene volcanic activity on the Capelo Peninsula (Faial Island, Azores): the paleomagnetic contribution. Geol Soc Am Bull 126:1164-1180

Di Chiara A, Moncinhattob T, ernandez Moreno CH, Pavón-Carrasco FJ, Trindade RIF (2017) Paleomagnetic study of an historical lava flow from the Llaima volcano, Chile. J South Am Earth Sci 77:141-149

Dzotsenidze NM, Khaburzaniya IA, Bagratishvili TD (1985) Report on the geological and paleomagnetic study of lava piles of the kazbek area in the greater caucasus aimed at their correlation, refinement of the age and determination of possible ore potential. KIMS, Tbilisi

Ertepinar P (2012) Archaeomagnetic study of five mounds from Upper Mesopotamia between 2500 and 700 BCE: further evidence for an extremely strong geomagnetic field ca. 3000 years ago. Earth Planet Sci Lett 357:84-98

Herve G, Lanos P (2017) Improvements in archaeomagnetic dating in western Europe from the late bronze to the late iron ages: an alternative to the problem of the Hallstattian Radiocarbon Plateau: improvements in archaeomagnetic dating in western Europe. Archaeometry. https://doi. org/10.1111/arcm.12344
Koronovskii NV, Demina LI (2003) Disappeared volcanoes of the main caucasus range. Priroda 10:37-43

Korte M, Constable C (2011) Improving geomagnetic field reconstructions for 0-3 ka. Phys Earth Planet Inter 188:247-259

Korte M, Donadini F, Constable CG (2009) Geomagnetic field for 0-3 ka: 2. a new series of time-varying global models. Geochem Geophys Geosyst. https://doi.org/10.1029/2008gc002297

Lebedev VA, Parfenov AV, Vashakidze GT, Chernyshev IV, Gabarashvili QA (2014) Major events in evolution of the kazbek neovolcanic center, greater caucasus: isotope-geochronological data. Dokl Earth Sci 458:1092-1098

Lebedev VA, Parfenov AV, Vashakidze GT, Gabarashvili QA, Chernyshev IV, Togonidze MG (2018) Chronology of magmatic activity and petrologicmineralogical characteristics of lavas of kazbek quaternary volcano. Greater Caucasus Petrol 26(1):1-28

Leonhardt R (2006) Analyzing rock magnetic measurements; the RockMagAnalyzer 1.0 software. Comput Geosci 32:1420-1431

Pavón-Carrasco FJ, Rodríguez-Gonzáles J, Osete ML, Torta JM (2011) A Matlab tool for archaeomagnetic dating. J Archaeol Sci 32(8):408-419

Pavón-Carrasco FJ, Osete ML, Torta JM, Santis AD (2014) A geomagnetic field model for the holocene based on archaeomagnetic and lava flow data. Earth Planet Sci Lett 388:98-109

Rebaï S, Philip H, Dorbath L, Borissoff B, Haessler H, Cisternas A (1993) Active tectonics in the lesser caucasus: coexistence of compressive and extensional structures. Tectonics 5:1089-1114

Roberts AP, Tauxe L, Heslop D, Zhao X, Jiang ZX (2018) A critical appraisal of the "day diagram". J Geophys Res: Solid Earth 123(4):2618-2644. https:// doi.org/10.1002/2017jb015247

Roperch P, Chauvin A, Lara LE, Moreno H (2015) Secular variation of the Earth's magnetic field and application to paleomagnetic dating of historical lava flows in Chile. Physics of the Earth Planet Inter 242:65-78

Sánchez-Moreno EM, Calvo-Rathert M, Goguitchaichvili A, Vashakidze GT, Lebedev VA (2018) Evidence of unusual geomagnetic regimes recorded in Plio-Pleistocene volcanic sequences from the lesser caucasus (Southern Georgia). esser caucasus (Southern Georgia). Geochem Geophys Geosyst 19:1429-1446. https://doi.org/10.1029/2017GC007358

Siebe C, Rodríguez-Lara V, Schaaf P, Abrams M (2004) Radiocarbon ages of Holocene Pelado, Guespalapa, and Chichinautzin scoria cones, south of Mexico City: implications for archaeology and future hazards. Bull Volcanol 66(3):203-225

Snowball I, Zillén L, Ojala A, Saarinen T, Sandgren P (2007) FENNOSTACK and FENNORPIS: varve dated Holocene palaeomagnetic secular variation and relative palaeointensity stacks for Fennoscandia. Earth Planet Sci Lett 255(1-2):106-116

Tauxe L (2010) Essentials of rock and paleomagnetism, 1st edn. University of California Press

Tema E, Kondopoulou D (2011) Secular variation of the earth's magnetic field in the balkan region during the last 8 millennia based on archaeomagnetic data. Geophys J Int 186(2):603-614

\section{Publisher's Note}

Springer Nature remains neutral with regard to jurisdictional claims in published maps and institutional affiliations. 